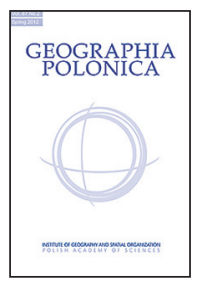 \\ INSTITUTE OF GEOGRAPHY AND SPATIAL ORGANIZATION \\ POLISH ACADEMY OF SCIENCES \\ www.igipz.pan.pl

\title{
DISTRIBUTION OF FOREIGN DIRECT INVESTMENT ACROSS THE NATIONAL URBAN SYSTEMS IN COUNTRIES OF CENTRAL AND EASTERN EUROPE IN 2013
}

\author{
Natalia Zdanowska \\ UMR 8504 Géographie-cités \\ Université Paris 1 Panthéon-Sorbonne \\ 13 rue du Four, 75006 Paris: France \\ e-mail: natalia.zdanowska@parisgeo.cnrs.fr
}

\begin{abstract}
This article aims to investigate the origin of foreign direct investment (FDI) in Central and Eastern Europe (CEE) and its spatial distribution among CEE headquarters in national urban systems. The conceptual framework is based on discussion of the role of metropolises. To provide a broad geographical scope the ORBIS database has been used, and its value has been discussed. The analysis shows that headquarters in capital cities were still attracting the greatest amount of foreign direct investment as of 2013, even when considerations are set at the level of different types of activity sector.
\end{abstract}

\section{Key words}

Central and Eastern Europe $\bullet$ cities $\bullet$ foreign direct investment $\bullet$ headquarters $\bullet$ spatial distribution

\section{Introduction}

The economic transition post-1989 and accession of the Central and Eastern European countries (CEECs) to the European Union since 2004 have been major stimuli to capital flows into the $\mathrm{CEE}^{1}$ economies in the forms of foreign direct investment (FDI), portfolio investments and loans (Dostál 2008; Pyka 2011).

\footnotetext{
${ }^{1}$ CEE will be used in the rest of the article as an abbreviation for Central and Eastern Europe, CEECs for Central and Eastern European countries.
}

The inflow of FDI is considered essential as the determinant of economic growth in the CEE region (Popescu 2014).The question of the origin of foreign ownership of capital in Central and Eastern Europe is clearly therefore of relevance to the evolution of economic control functions. Throughout the 1990s and 2000s this question mainly concerned companies from the European Union. Parentage links between firms in different CEE countries that existed before 1989 were preserved but played a secondary role. The analysis of the spatial distribution of foreign ownership of capital and the 
presence of corporate headquarters of major multinational enterprises across the settlement network is of value when it comes to the formation of new "command-and-control functions" of cities (Csomós \& Derudder 2014).

Immediately following the fall of the Berlin Wall, CEECs were characterised by a centralisation of all economic and administrative management centres in the capital city, as a reflection of the planned economy approach (Śleszyński 2002). Notwithstanding anticipated tendencies for spatial structure to deconcentrate following reforms of the administrative division, firms' headquarters remained largely located in capitals and other metropolitan areas throughout the 1990s and 2000s (Wyżnikiewicz 1997; Guzik \& Gwosdz 2000; Nowosielska 2001; Wendt 2001; Dostál 2008). There remains no doubt as to the major role metropolises play in attracting foreign direct investment, as they concentrate major economic functions (Sassen 1991; Taylor, 2001; Vandermotten et al. 2010) and attract the most qualified and dynamic activities (Pumain \& Rozenblat 2007).

Study of the origin of foreign direct investment and its spatial distribution in regard to CEE firms' headquarters in 2013 will permit discussion of regularities to the locating of such investment.

Foreign direct investment is a "cross-border investment by a resident entity in one economy with the objective of obtaining a lasting interest in an enterprise resident in another economy" (OECD 2013: 50). The main difference between FDI and portfolio investment is that, in the latter case, an investor purchases equities in foreign companies, while in the former an investment leads to substantial influence or effective control of the decision-making process in a foreign company. The basic criterion representing an investor's influence on the management of an enterprise is ownership of at least 10\% of the voting power of the enterprise, while $50 \%$ or greater ownership implies complete power in terms of decisions (OECD 2013). The latter criterion will be considered in the article as a whole.
The purpose of this paper is to identify the origin of FDI in the CEECs, and to characterise the cities there, most attractive as headquarters for foreign investors in 2013. The following questions will be addressed: who are the main investors in Central Eastern Europe and what is the state of intra-CEE relations in terms of FDI? What type of cities in the CEECs are involved in the FDI inflows and how is this related to urban patterns of the different national systems in the CEECs? And how does the location of foreign ownership vary between the different activity sectors that firms in the CEECs represent?

The originality of this article lies in its answering these cognitive questions by means of the ORBIS database. This is a rare source as it permits simultaneous identification of the exact locations in cities of the headquarters of foreign-owned companies in the CEECs and the owner firm based abroad. Other databases providing the same information are either at national level or do not exist in the CEECs ${ }^{2}$. Moreover, it allows for work with a comparative perspective throughout the whole CEE region. In addition, it permits comparisons of these distributions of FDI within different types of activity sector to be made, as the database indicates for each firm (owner and owned company) the $\mathrm{NACE}^{3}$ code division (Albert-Bohan 2015; Finance 2016).

\section{Literature review}

Studies on the distribution of enterprise management locations have been conducted using various methodologies, in various fields. Some work has been focused on a global scale, as in the case of research on the spatial concentration of IT corporate headquarters (Kilar 2009, 2014, 2015) or the location of headquarters in the industry sector (Evans 1973), while other studies have investigated

2 This has been checked by the author in the course of fieldwork done in all of the CEE capital cities in the years 2014-2015.

${ }^{3}$ General Industrial Classification of Economic Activities within the European Communities. 
the general reasoning underpinning the locations of firms (Kamp 2007).

In relation to Central and Eastern Europe, the majority of studies have focused on foreign direct investment in these countries ( $\mathrm{Hu}$ nya 1998; Luc 2000; Marinova \& Marinov 2003; Pavlínek 2004; Hilber \& Voicu 2010). Work has for example centred on the contrasting geographies of investment characterising the Czech and Slovak Republics (Pavlínek \& Smith 1998), while other studies have sought to characterise the inflow of FDI into the CEECs, as a source of long-term capital inflow reinforcing domestic funds and introducing the new technology and managerial skills that companies seeking to restructure tend to require (Popescu 2014). As many studies of FDI have been of an economic nature (Karaszewski 2004; Pakulska \& PoniatowskaJaksch 2006), these in most cases employ econometrical modelling based on aggregate data - as for example in the case of Bulgaria (Sakali 2013). Such work does not permit analyses at city level. Fundamental studies of a geographical nature regarding the location of FDI have been concerned with the Polish transport sector (Taylor \& Ciechański 2013, 2014), or manufacturing (Domański et al. 2000; Guzik \& Gwosdz 2000; Domański 2001). Others investigate the determinants underpinning the locating of FDI in Polish regions (Cieślik 2005; Domański 2011), or individual sectors (Cieślik 2013).

Many studies have concerned FDI in other CEECs, such as Hungary - and its finance and industrial sectors (Gál 2013; Kiss 2014; Lux 2015), the Czech Republic (Vančura 2006; Pavlínek et al. 2009; Sucháček \& Báranek 2012) and Slovakia (Buček 2012), with the latter studies dealing with various different sectors. FDI allocation to different regions has been investigated in Romania (Goschin et al. 2010; Popescu 2012) and in Bulgaria (Bitzenis 2004), in the latter case with a view to elucidating the low level of interest shown by potential Western investors. Finally, Slovenia (Hamilton et al. 2005) and Croatia (Jovančević 2007) have also been investigated in terms of FDI inflow.
In each case, it is rare for any studies to move down to the level of individual cities. It is therefore the intention that this article should contribute to broader knowledge on the CEE cities in which foreign owners of firms' capital do or do not choose to locate, with a comparative approach to all of the CEECs in 2013 being taken. Most of the time, analysis on this topic has been carried out at national level only. We can cite here the valuable literature on foreign control functions of Polish firms, mainly generated by Śleszyński (2002, 2007, 2014). In addition, this paper intends to compare and contrast the distribution of investment among different sectors of economic activity. This kind of analysis for the whole CEE region at city level is indeed rather scarce (Rozenblat \& Dillelo 2014), and where it does exist it tends to concern specific sectors only, e.g. the automotive sector (Albert-Bohan 2015).

\section{Data and Methodology}

The analysis of foreign holder control over Central and Eastern European economic management centres and the economic attractiveness of metropolitan areas in the CEECs has been driven by the ORBIS database produced by the Brussels-based Bureau Van Dijk (BvD). The database Połaczenia Świat (hereafter cited as The World's Connections), as developed by Śleszyński (described in detail in Śleszyński 2007) has also been used to confirm the results concerning the structure and origin underpinning the foreign ownership of Polish firms as of 2004.

The Bureau Van Dijk specialises in collecting private company information, and collaborates with at least 100 sources from around the world. ORBIS is thus a very extensive global database encompassing some 200 million firms throughout the world, and around 86 million companies in Europe alone $e^{4}$. It has

\footnotetext{
${ }^{4}$ ORBIS is concurrent with the database produced by Dun and Bradstreet, the latter being a less complete one verified after a specific analysis conducted by Professor Céline Rozenblat from the University of Lausanne in 2004-2005, as based on management online reports of the biggest groups.
} 


\section{STRENGTH $=a b / 100$}

a - share of capital of a firm headquartered in a CEE owned by a foreign company

$b$ - annual revenue of the CEE firm in 2013

To give a fictional example: a firm headquartered in London owns $50 \%$ of the capital of a company based in Warsaw, whose annual revenue in 2013 was of 1 milliard euros. The strength of the London-Warsaw company relationship is thus equal to 500 million euros.

Figure 1. The strength indicator: a measure of the amount of foreign investment in CEE firms' capital in euros

been updated regularly since being founded in 2002, and provides financial and geographical information about headquarters, shareholders, subsidiaries and direct ownership. Taken together, such data allow company hierarchies and parentage links to be reconstructed $^{5}$. The reliability of the database has been proven by many researchers (Gautier 2012; Finance 2014; Albert-Bohan 2015; Rozenblat \& Bellwald 2015). In the case of the work described here, the variables from the database that have been made use of - for both foreign owners and owned firms in CEE are company name, geographical coordinates and annual revenue, as well as the direct foreign-firm ownership of a given CEE firm's capital, expressed in percentage terms.

ORBIS resembles all databases in having certain weaknesses. Information is not complete in the case of every firm, for example, though $50 \%$ of missing geographical coordinates have been added by the author, while annual revenues of the largest firms have been checked against information on the latter's own websites. Another disadvantage is that ORBIS only indicates where firms are headquartered, as opposed to where their

\footnotetext{
${ }^{5}$ The information from ORBIS on the firms, as bought by the University of Lausanne concern: names of the firms, exact locations of headquarters (postal address, city, country), annual revenues (as indicated for the largest companies), numbers of employees, fourdigit NACE codes (Statistical Classification of Economic Activities in the European Community, NACE Rev 2.1 2008 for 2013) indicating the field of activity of each firm and the percentage of participation of firms in other firms' capital ( $60 \%$ of information available).
}

production and service activities are located. This leaves results regarding locations in cities as potentially biased, given that a different approach may be required to the study of headquarters and the real locations of production. A demonstrable example concerns Skoda Auto, which is headquartered in Prague, but has its production plant in Mlada Boleslav.

For the purposes of the work described here, a STRENGTH ${ }^{6}$ indicator was therefore constructed (Fig. 1), by reference to data from ORBIS as treated by Śleszyński (2007). The STRENGTH indicator quantifies the cumulated value of invested foreign capital in a CEE firm in euros, and at the same time reflects the force of such intra-companies relations. In the article overall, only possession of $50 \%$ or more of a CEE firm's capital by foreign companies has been considered sufficient to qualify as clear 'foreign control' of a CEEC-based firm.

Analysis based on the database has entailed the use of spatial analysis methods accompanied by GIS visualisation. A division into four parts has been pursued, into EU (European Union), NON-EU, CEEC and post-communist countries outside the EU. The data has already been allocated in the database following the 'Statistical Classification of Economic Activities in the European Community' (NACE). However for present purposes the manufacturing industry sector has been

\footnotetext{
6 The STRENGTH indicator has been calculated by P. Śleszyński by multiplying the part of the shares held by foreign institutions in a given firm's capital headquartered in Poland by the size of the annual revenues of this Polish company.
} 
aggregated into high-, medium high-, medium low- and low-technology categories, following the Eurostat division based on NACE codes (Eurostat 2009). Similarly, a distinction has been drawn between knowledge-intensive services (KIS) and less-knowledge-intensive services (LKIS) (Eurostat 2009) ${ }^{7}$.

\section{Origins of the main foreign investors in the CEEC region}

The ORBIS database provides information on 7696 Central and Eastern European firms with foreign ownership of capital (Tab. 1$)^{8}$. Throughout the analysis of the STRENGTH indicator reflecting the amount invested by foreign companies in Central and Eastern European firms (see Fig. 1 and also Śleszyński 2007), it is possible to note a clear prevalence among firms owning more than $50 \%$ of the capital of CEE companies of European Union origins. This is true to the tune of $82.4 \%$ (Tab. 2). More specifically, this intra-EU ownership is mainly seen to involve companies from The Netherlands (24.1\%), Germany (14.4\%) and France (12.3\%). The highest single example of FDI in any of the CEECs as of 2013 was that generated by Volkswagen International Finance NV (based in Amsterdam), which has a 10-billioneuro investment in Skoda Auto a.s. in Prague. The second highest single inflow of FDI was produced by Lisbon-based Jeronimo Martins SGPS s.a. as owner of Jeronimo Martins Polska s.a. in Kostrzyn, Poland (a stake of 5.7 bn euros). The German company E.ON SE based in Düsseldorf is in turn the entire owner of $\mathrm{E}$. ON in Budapest, which is an investment worth 2.7 bn euros. The highest level of investment by a French-based entity is in turn that generated by the Paris-headquartered

\footnotetext{
7 In Śleszyński 2015, NACE provided a basis for the aggregation of industries into four major economic sectors: agriculture (section $A$ ), industry $(B, C, D, E, F)$, lessspecialised services $(G, H, I, S, T)$ and highly-specialised services (J, K, L, M, N, O, P, Q, R, U).

8 The total number of companies taking into account various types of annual revenue and all types of percentage of ownership of capital (from 1 to 100\%), with no missing information.
}

Arcelormittal France, as owner of Arcelormittal Poland s.a. in Dąbrowa Górnicza, Poland (3.5 bn euros).

This ostensibly EU-dominated situation where origin of FDI is concerned, has gained confirmation in cited and sourced literature (Domański 2001; Korcelli-Olejniczak 2004, 2012; Taylor \& Ciechański 2013; Śleszyński 2007, 2008, 2014, 2015). The results in 2013 seem to show a historical permanence to this origin, given that investors from the European Union Member States were already of great relevance in the 1990s, just before the CEECs acceded to the European Union ( Carstensen \& Toubal 2004; Popescu 2014). As of 1999, the FDI flows came mainly from companies with HQs in Germany, The Netherlands or Austria. The proximity to the EU in general, and such member States in particular, stimulated "market-seeking investments of EUbased multinationals" (Carstensen \& Toubal 2004: 6), with the aim being to draw benefit from the large privatisation projects ongoing in the CEE region.

Foreign ownership from non-European countries thus accounts for just $8.6 \%$ of overall FDI. This leaves firms from the United States of America second to the EU states, with its leading position where the non-European countries are concerned. However, the percentage of the overall level of FDI is just 2.7\% in this case. By the late 1990s, the position of the USA was already of relevance, in particular in the Visegrad countries (Poland, the Czech Republic, the Slovak Republic and Hungary). Together, these four states accounted for about $90 \%$ of US investment in the wider region (Carstensen \& Toubal 2004).

Ownership originating in post-communist countries beyond the European Union only constitutes a very rare phenomenon (see also Rozenblat \& Di Lello 2014). It barely represents $0.7 \%$ of the total number of ownership links in the CEE region, and mainly concerns the Russian Federation (0.6\%). Ownership links with cities from the ex-USSR exist, but take a very small share of overall investment (see also Lepesant 2011; Rozenblat \& Di Lello 2014; Komornicki \& Szejgiec 2015). However, 
Table 1. Number of firms with foreign ownership of capital in each Central and Eastern European country, as detailed in the ORBIS database as of 2013

\begin{tabular}{|l|c|c|c|c|c|c|c|c|}
\hline & Poland & Czechia & Romania & Hungary & Slovakia & Croatia & Bulgaria & Slovenia \\
\hline$\geq 50 \% *$ & 2005 & 1614 & 1156 & 574 & 440 & 337 & 241 & 234 \\
Total $* \star$ & 7263 & 4288 & 3283 & 3483 & 640 & 934 & 964 & 627 \\
\hline
\end{tabular}

* Number of firms with foreign ownership of capital equal to or greater than $50 \%$.

** The total number includes all firms indicated in the database with missing information on annual revenues, employees and percentage of foreign ownership, which had to be excluded from analysis.

NB: The ORBIS database is a very powerful tool, if within a few limits. Important work has thus been carried out by the author, with a view to the database being corrected where missing annual totals for revenue and geographical coordinates are concerned.

Source: ORBIS database, BVD, 2013.

Table 2. Origin of foreign firms owning more than $50 \%$ of the capital in given Central and Eastern European firms as of 2013, expressed in terms of the total STRENGTH generated by the foreign ownership in the CEE region

\begin{tabular}{|c|c|c|c|c|c|c|c|c|}
\hline $\begin{array}{l}\text { Foreign ownership } \\
\text { in CEE from }\end{array}$ & \multicolumn{2}{|c|}{ EU } & \multicolumn{2}{|c|}{ non-European } & \multicolumn{2}{|c|}{ Other CEE } & \multicolumn{2}{|c|}{$\begin{array}{l}\text { Non-EU } \\
\text { post-communist } \\
\text { countries }\end{array}$} \\
\hline \multirow{9}{*}{$\begin{array}{l}\text { \% of total STRENGTH } \\
\text { generated by foreign } \\
\text { ownership in CEE }\end{array}$} & \multicolumn{2}{|c|}{82.4} & \multicolumn{2}{|c|}{8.6} & \multicolumn{2}{|c|}{8.3} & \multicolumn{2}{|c|}{0.7} \\
\hline & $\mathrm{NL}$ & 24.1 & $\mathrm{KR}$ & 3.6 & $\mathrm{HU}$ & 2.5 & RU & 0.6 \\
\hline & DE & 14.4 & US & 2.7 & $P L$ & 2.3 & RS & 0.02 \\
\hline & FR & 12.3 & $J P$ & 1.4 & HR & 1.1 & UA & 0.009 \\
\hline & AT & 8.9 & $\mathrm{CA}$ & 0.3 & $\mathrm{CZ}$ & 0.7 & BA & 0.002 \\
\hline & UK & 5 & $\mathrm{IL}$ & 0.2 & SK & 0.7 & MK & 0.001 \\
\hline & $\mathrm{CH}$ & 4.1 & AS & 0.1 & $\mathrm{RO}$ & 0.7 & & \\
\hline & IT & 3 & $\mathrm{BM}$ & 0.1 & SI & 0.2 & & \\
\hline & other & 10.4 & other & 0.2 & $B G$ & 0.1 & & \\
\hline
\end{tabular}

* European Union members excluding the CEECs, with Norway and Switzerland nevertheless included.

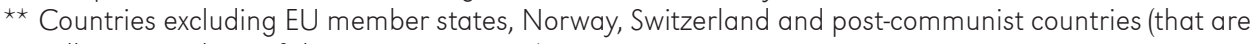
still non-members of the European Union).

$\star \star \star$ Intra-CEE ownership only (excluding ownership between firms within a CEE country).

Country codes:

AS - Australia
AT - Austria
BA - Bosnia and Herzegovina
BG - Bulgaria
BM - Bermuda
CA - Canada
CH - Switzerland
CZ - Czechia
DE - Germany

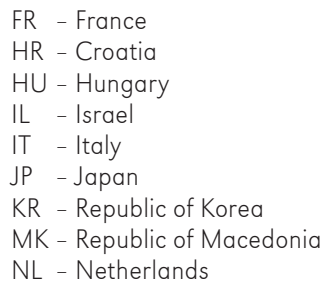

$\mathrm{PL}$ - Poland

RO - Romania

RS - Serbia

RU - Russia

SI - Slovenia

SK - Slovakia

UA - Ukraine

UK - United Kingdom

US - United States of America

Source: ORBIS database, BVD, 2013 
as was already alluded to above, it is nothing more than direct ownership that is analysed here. Indirect ownership is in fact present in the CEEC region, as capital from Russia is quite often injected via intermediary third firms for example headquartered in the EU Member State that is Cyprus.

An interesting fact is that foreign ownership of capital coming from other CEECs represents $8.3 \%$ of total FDI (Tab. 2), a level close to that in the case of Non-European companies $^{9}$. It is Hungarian and Polish firms that are the main investors across the CEECs, even if respectively they account for just $2.5 \%$ and $2.3 \%$ of the total.

\section{Intra-CEE company investments and the proximity effect}

Intra-CEE relationships would seem worthy of more detailed investigation, even if they account for just $8.3 \%$ of FDI overall (Tab. 2). In terms of received amounts of FDI, that coming from companies headquartered in other CEECs represents just 0.8 and $0.4 \%$ of the totals characterising Poland and Hungary respectively, as opposed to $4.1 \%$ in the case of Romania and $5.1 \%$ for Czechia. In further contrast, this source seems to play a quite relevant role in Croatia, where the percentage of total FDI is as high as $33.3 \%$, and in Slovakia, where it is $20.3 \%$ (Tab. 3).

It further seems that relations between CEE cities are very unbalanced. Slovakia is the country most invested in (with 34\% of total investment), as followed by Czechia (26\%) and Croatia (13\%). Hungary in turn ranks highest as a source of investment in other CEE cities (44\%), as followed by Poland $(21 \%)$ and Czechia (14\%) (Tab. 3). Bulgaria and Croatia are the countries investing least, while Hungary and Slovenia are those least invested in, in this particular way. Given that the

\footnotetext{
${ }^{9}$ Within these intra-CEE ownership relationships just $12 \%$ of owned firms generate an annual revenue greater than 24 million euros, which is to say that CEE ownership mainly concerns medium-sized and small firms.
}

only country in which Romania had invested as of 2013 was Bulgaria, the disproportionality to the investment process is made clear.

At city-to-city level, Budapest and Bratislava are the most connected cities in terms of foreign investment (mainly due to $\mathrm{Mol}$ Magyar Olaj-Es Gazipari rt. being the source of 4.7 bn euros of the capital in Slovnaft a.s.) (Tab. 4). The second most powerful relationship in terms of investment size is that pertaining between Warsaw and Prague, given that Polski Koncern Naftowy Orlen S.A. owns Unipetrol a.s., on the basis of an investment worth 2.4 bn euros.

Results in Table 3 reflect the differing investment capabilities of the different CEECs, not least given their differing levels of development (Lux 2010). An interesting point worth stressing concerns historical background (and privileged relationships) present when the Austrian, Prussian, Russian and Ottoman Empires held sway in the 18th and 19th centuries, and/or present in the communist era (Lepesant 2011; Zdanowska 2015), are still seen to exert an impact on the current orientation of investments within the CEE region. Romanian firms are most invested in by Hungarian ones (to the tune of 870.7 million euros). In fact, territory of these two countries (especially through the Transylvanian region) had much in common in the days of the Austro-Hungarian Empire. To date, Slovak firms continue to own most of the intra-CEEC capital in Czech firms (1.45 bn euros), with Czech firms conversely owning most CEEC capital in Slovak companies (1.42 bn euros). This reflects the privileged relations present while Czechoslovakia still existed (which it did until 1993). Similarly, Slovenia is the main CEEC locating capital in Croatia (785.1 million euros) and vice versa, with Croatia investing 473.6 million euros in Slovenian companies. Notwithstanding sometimes tense relations following the collapse of Yugoslavia from the late 1980s, the impact of past exchanges within that country is still to be seen clearly (see also Lepesant 2011).

The 'proximity effect' is also very important in explaining these selective relationships 
in CEECs in terms of the origin of intra-CEE ownership of capital, especially in the case of Poland (Fig. 1) and Croatia (Fig. 2). In fact, Figure 1 reveals that CEEC-based owners of Polish firms' capital are mainly from Czechia, Slovakia and Hungary, which are all adjacent to, or located not far from, Poland's borders. In contrast, no direct ownership from
Romania or Bulgaria was registered in the database as of 2013. An interesting fact is that foreign CEEC-based investors located most capital (600 million euros) in Polish firms based in Kraków, as opposed to in Warsaw, as might have been expected (Fig. 2). The latter fact reflects the Slovak firm Slovnaft a.s. (headquartered in Bratislava) being the

Table 3. Strength of investments between Central and Eastern European countries in thousands of euros

\begin{tabular}{|c|c|c|c|c|c|c|c|c|c|c|}
\hline & \multicolumn{8}{|c|}{ Destination } & \multirow{2}{*}{$\%$} \\
\hline & & $C Z$ & $P L$ & HU & SK & HR & SI & BG & RO & \\
\hline \multirow{10}{*}{ : 돈 } & $C Z$ & & 191.2 & 2.1 & $1,417.4$ & 1.3 & 0.5 & 794.1 & 752.1 & 14 \\
\hline & $P L$ & $4,246.2$ & & 35.1 & 103.4 & 34.0 & 3.3 & 1.3 & 268.6 & 21 \\
\hline & $\mathrm{HU}$ & 110.2 & 115.4 & & $6,199.9$ & $2,247.7$ & 220.8 & 355.9 & 870.7 & 44 \\
\hline & SK & $1,444.5$ & 719.1 & 122.7 & & 2.4 & 36.1 & 3.7 & 0.4 & 10 \\
\hline & $\mathrm{HR}$ & 31.3 & 28.7 & 9.2 & 103.4 & & 473.6 & 0.02 & 0.2 & 3 \\
\hline & SI & 30.8 & 7.7 & - & 1.1 & 785.1 & & 3.7 & 85.4 & 4 \\
\hline & $B G$ & 2.5 & - & - & - & 0.2 & - & & 9.7 & 0 \\
\hline & RO & - & - & - & - & - & - & 953.8 & & 4 \\
\hline & $\%$ & 26 & 5 & 1 & 34 & 13 & 3 & 9 & 9 & \\
\hline & \%TOTAL & 5.1 & 0.8 & 0.4 & 20.3 & 33.3 & 8.6 & 6.8 & 4.1 & \\
\hline
\end{tabular}

* Represents - for the given country - the share of CEE investment as a proportion of the total represented by investment from all countries

Source: ORBIS database, BVD, 2013.

Table 4. Classification of investments between Central and Eastern European companies aggregated at city-to-city level in terms of total foreign investment in millions of euros

\begin{tabular}{|l|c|}
\hline \multicolumn{1}{|c|}{ City-to-city investment } & Total foreign investments in millions of euros \\
\hline BUDAPEST-BRATISLAVA & $4,668,300$ \\
WARSAW-PRAGUE & $2,432,733$ \\
BUDAPEST-ZAGREB & $2,152,619$ \\
JASZFENYSZARU-GALANTA & $1,531,612$ \\
BRATISLAVA-PRAGUE & $1,349,063$ \\
BUCHAREST-SOFIA & 940,120 \\
KATOWICE-KRALUPY NAD VLTAVOU & $1,248,719$ \\
BUDAPEST-BUCHAREST & 791,779 \\
PRAGUE-BRATISLAVA & 758,104 \\
PRAGUE-SOFIA & 692,648 \\
\hline
\end{tabular}

Source: ORBIS database, BVD, 2013. 
owner of the Kraków-based Slovnaft-Polska S.A. Slovnaft a.s specialises in the manufacture of refined petroleum products, while the subsidiary in Kraków engages in the retail sale of automotive fuel.

In turn, the Hungarian firm Egis Gyogyszergyar rt. headquartered in Budapest specialises in the manufacture of basic pharmaceutical products and pharmaceutical preparations. As of 2013 it was owner of Egis Polska Dystrybucja Sp. z 0.0., with its seat in Warsaw, and operating in the wholesaling of pharmaceutical goods. The Croatian firm Podravka Prehrambena Industrija d.d. from the food-product sector had a $100 \%$ capital stake in Podravka
Polska Sp. z o.o., which is located in Kostrzyn nad Odra (west-central Poland).

The 'proximity effect' is also particularly visible in the case of Croatia (Fig. 3). Relations between Slovenian and Croatian businesses were among the most privileged within the CEEC region as of 2013 (with 784.1 million euros invested) (Tab. 3), and Slovenian-owned companies mainly located in Zagreb (Fig. 3). The company Petrol Slovenska Energetska Druzba d.d. headquartered in Ljubljana owned Petrol d.o.o. based in Zagreb, the later generating the highest STRENGTH to be noted in Croatia in 2013. The second Croatian company generating the most important STRENGTH was

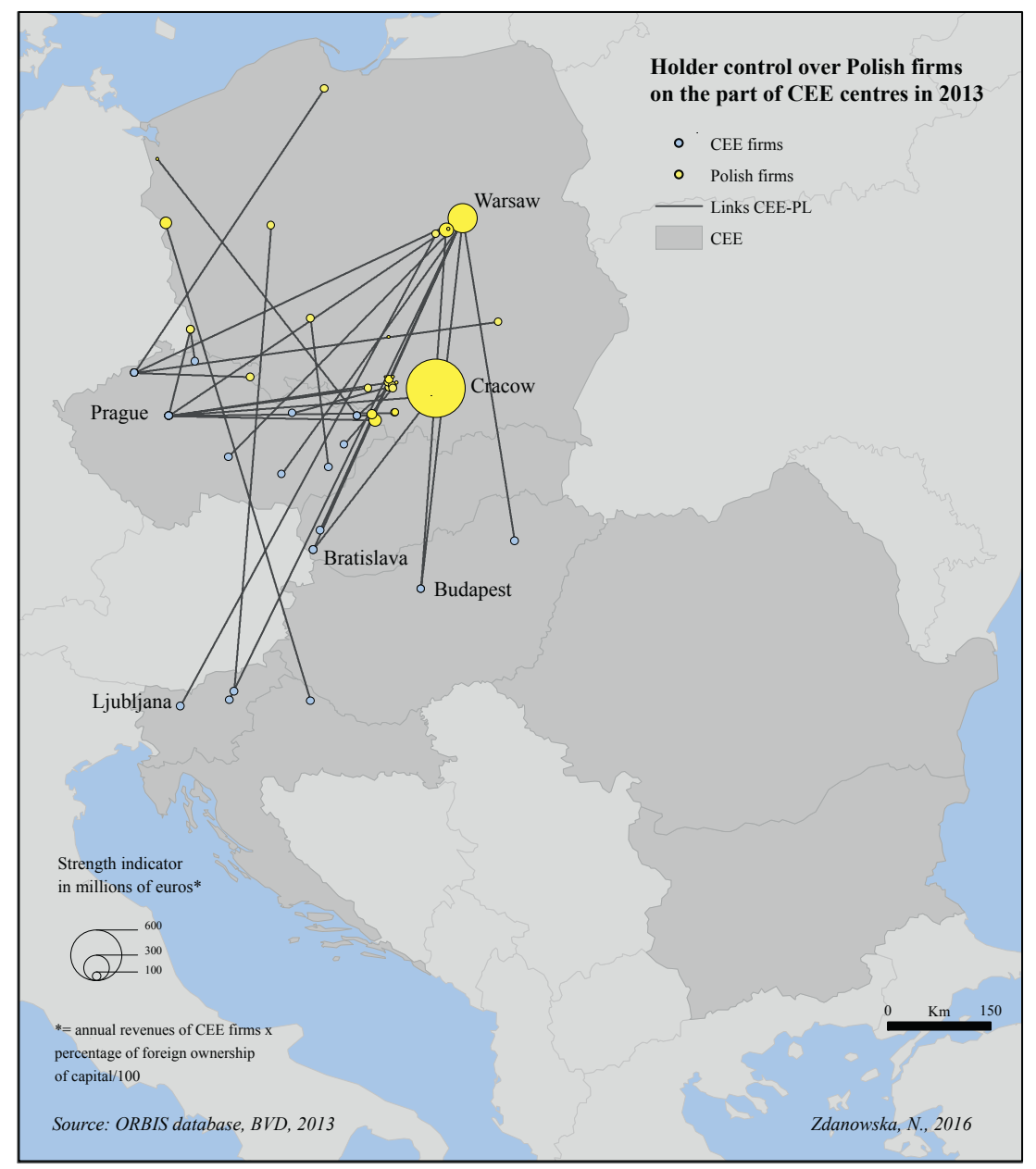

Figure 2. Central and Eastern European holder control over Polish economic management centres in 2013 
Tifon d.o.o. in Zagreb, which is owned by Mol Magyar Olaj-Es Gazipari rt. located in Budapest. Both firms specialise in activity support of petroleum and natural gas extraction.

The Romanian case thus represents an exception to this well-documented 'proximity effect'. Romania is the one of the countries most invested in by forms from the CEECs, but these are mainly from Hungary, Czechia and Poland (see Tab. 3), which are not necessarily borderland countries. Bulgarian investments in Romanian companies are in turn quite negligible(Fig. 4). As of 2013, Mol Magyar Olaj-Es Gazipari rt. headquartered in Budapest owned Mol Romania Petroleum Products Srl in Bucharest, with this representing the greatest fraction of foreign investment in Romania.

Romania in fact represents an interesting market to enter from the economic point of view. FDI there has primarily concerned activities like business and other management consultancy activities; production of electricity; trade in electricity; water collection, treatment and supply; wholesaling of wood, construction materials and sanitary equipment and the development of building projects. Investments in the agricultural sector were rather scarce, and concerned only wine and



Figure 3. Central and Eastern European holder control over Croatian economic management centres in 2013 


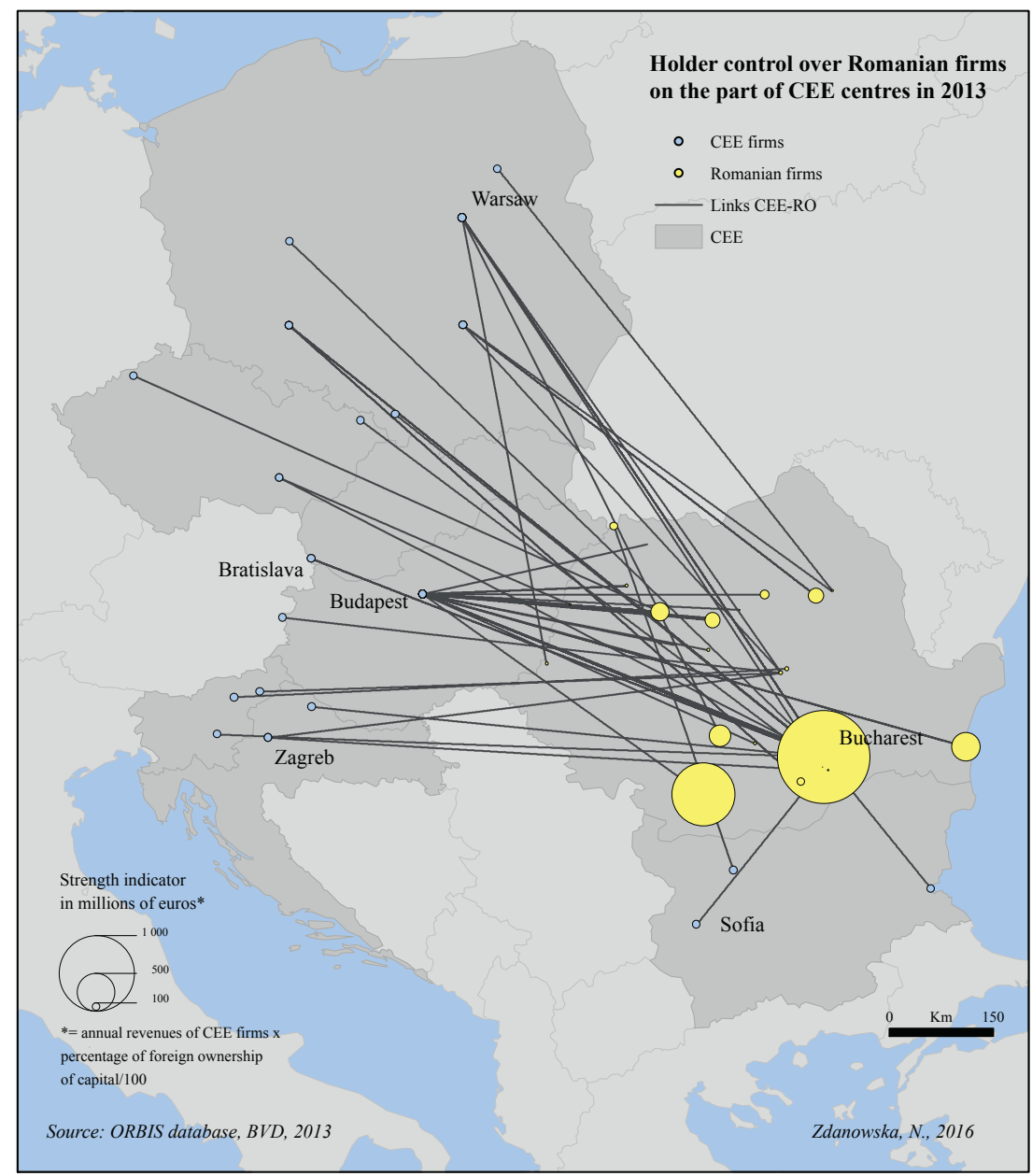

Figure 4. Central and Eastern European holder control over Romanian economic management centres in 2013

beverage production. For example, Ambra S.A. based in Warsaw was the source of half of the capital in Zarea S.A., which operates in winemaking and is headquartered in Bucharest.

\section{CEE cities receiving FDI}

Following aggregation of all CEE firms at city level, the analysis reveals that capital cities still prove most attractive to international investors - from among other possible CEE urban entities - as is attested to by levels of investment in Euros (Fig. 5).
In 2013, Prague was the city attracting the highest level of foreign investment in terms of the absolute amount of capital invested (i.e. 75 bn euros). The three most important investors there were Volkswagen International Finance NV of Amsterdam (owning Skoda Auto a.s.), RWE Gas International N.V. of S Hertogenbosch (owning RWE Transgas a.s.) and Alpiq Energy SE of Niedergosgen (owning Alpiq Central Europe AG).

Warsaw was the number-two destination for FDI in the CEECs in this regard, with 52 bn euros invested. Paris-based Carrefour was 


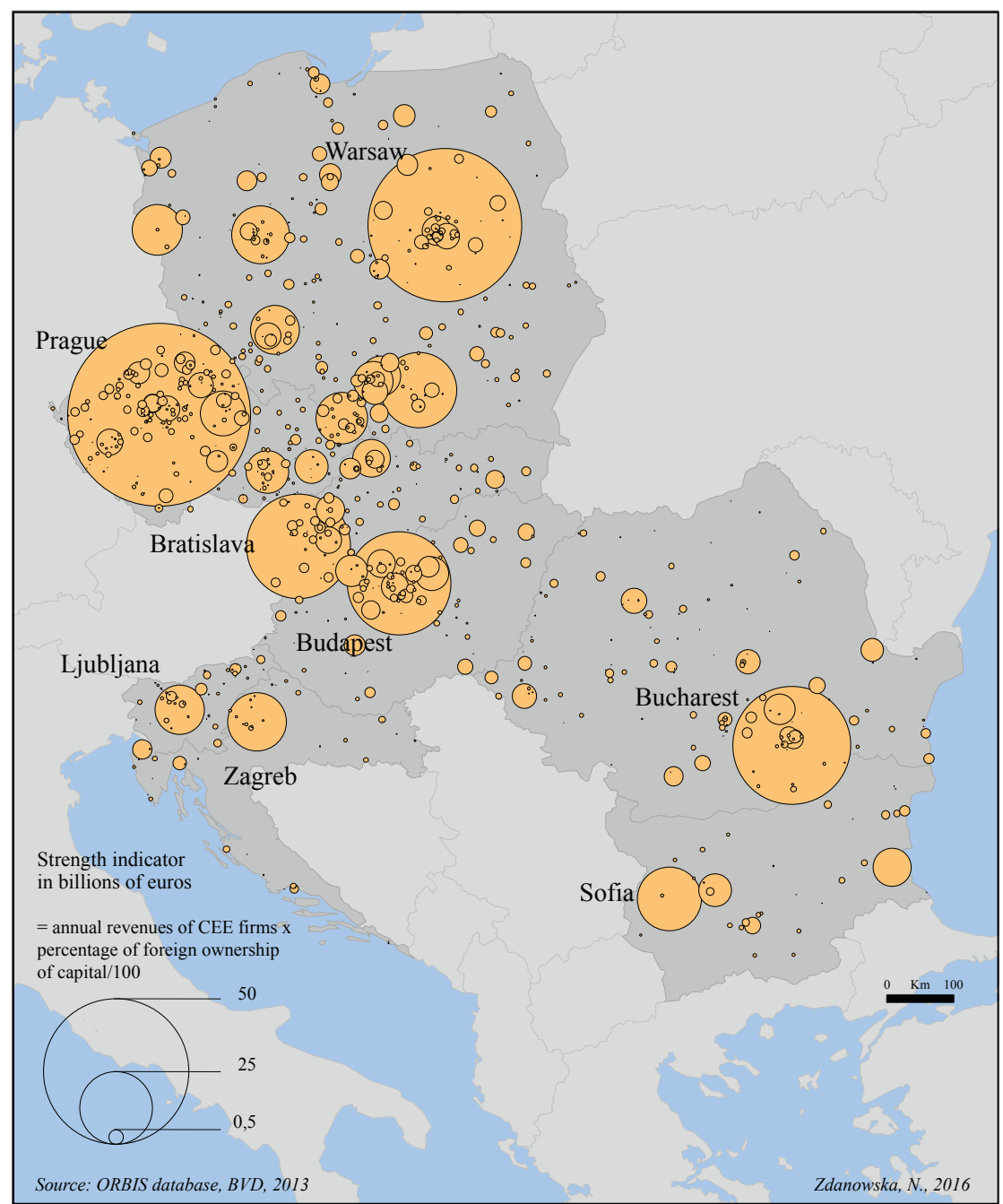

Figure 5. The STRENGTH of foreign investments in the CEECs aggregated at city level in 2013, in billions of euros

the largest investor (owning Carrefour Polska Sp. z.o.o.), followed by Metro Cash \& Carry International Holding B.V. from Amsterdam (owning Metro Cash \& Carry Polska S.A.) and Telekom Deutschland Gmbh from Köln (owning Polska Telefonia Cyfrowa S.A.).

After the Czech and Polish capitals there follows Bucharest, which has attracted a total of 31 bn euros in FDI (with Renault of Paris owning Automobile-Dacia S.A. as the first investor). Then comes Bratislava with 24 bn euros now invested (with Volkswagen International Finance NV owning Volkswagen Slovakia a.s. as number 1). Budapest ranked fifth in terms of total FDI inflow (23 bn), then came Kraków (13 bn), Sofia (9 bn) and Zagreb (7 bn). In all the latter cities the first investors were practically all from the oil and gas sector (E.on SE in Düsseldorf owning E.on Foldgaz in Budapest, Omv Refining \& Marketing Gmbh in Vienna owning Omv Bulgaria ood in Sofia and Viva International Marketing Gmbh owning 
Omv Hrvatska d.o.o. in Zagreb). The exception here was Kraków (whose top investor has been Exos spa based in Torino, which owns Fiat Auto Poland S.A.). Ljubljana ranked with 5.6 bn euros in foreign investment, and thus came behind such urban localities in Czechia and Poland as Poznań (7 bn), Ostrava (5.9 bn) and Kostrzyn (5.7 bn). An urban pattern for each CEEC can be recognized in this economic repartition (Sucháček 2013). More precisely it seems that FDI attraction and city size are related.

Nevertheless if the STRENGTH of foreign ownership links aggregated at national level is taken into account, Poland would maintain first position. It can then be deduced that in Poland these foreign investments are more widely dispatched to other cities, as opposed to just the capital city (Tab. 6). In fact, data presented in Table 6 confirm the idea that, in comparison with other CEE capitals, Warsaw manifests a more limited (42\%) concentration in terms of the total STRENGTH of foreign ownership at national level, which means that the economic management centres controlled by foreign owners were more likely to be located in secondary cities than is the case in the other CEE countries. Cities such as Prague, Bucharest, Ljubljana and Zagreb had concentration ratings of more than $60 \%$, revealing a certain over-dominance with
Table 5. STRENGTH generated in each of the CEECs' capital-cities as a share of the total for each country

\begin{tabular}{|l|c|}
\hline & \% TOTAL STRENGTH \\
\hline Warsaw & 42 \\
Sofia & 54 \\
Budapest & 58 \\
Bratislava & 61 \\
Bucharest & 64 \\
Prague & 64 \\
Ljubljana & 65 \\
Zagreb & 87 \\
\hline
\end{tabular}

Source: ORBIS database, BVD, 2013.

regards to countries' capital cities as economic centres. This phenomenon is related to the urban patterns in each CEEC (Zdanowska 2015). In terms of population, Poland's urban system is considered the most polycentric in any of the CEECs, which means that there is no dominance of the capital city over other cities in the urban hierarchy. However if we take into account the connectivity of Polish cities within economic networks the urban repartition is not as equilibrated and polycentric (Zdanowska 2016), though still more

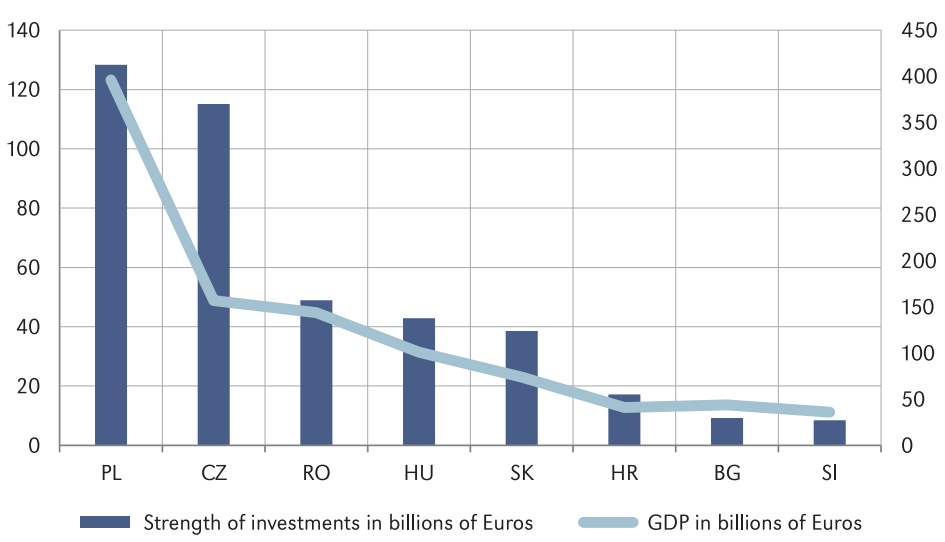

Figure 6. The strength of foreign investments in each CEEC (where more than 50\% of capital is held), and their respective GDP in billions of Euros in 2013

Source: ORBIS database, BVD, 2013. 
so than in other CEECs, such as Czechia, Hungary, Romania and Croatia (which are rather monocentric urban systems).

Generally speaking, FDI inflows are related to the magnitude of the economy, as is in turn reflected by the host country's GDP (Popescu 2014). It seems that, in the CEECs, the quantity of foreign investment in each country is proportional to its GDP in 2013: the higher the GDP, the more prevalent foreign investments are in the given country (Fig. 6). Indeed, Poland had the highest GDP among the CEECs, at the same time also attracting the largest amount of foreign investment among the CEECs in 2013. However, there might be some endogeneity in this relationship, as Czechia's GDP and FDI inflow are not exactly proportional.

\section{Investment in CEE cities by activity sector}

An analysis of the repartition of firms owned by foreign investors between CEE cities and by reference to different types of sector was conducted on the basis of the Eurostat division of manufacturing industry and service sectors into the categories: high-technology ${ }^{10}$, medium-high-technology 11, medium-low-technology ${ }^{12}$, low technology ${ }^{13}$, knowledge-intensive

10 The manufacture of basic pharmaceutical products and pharmaceutical preparations; computer, electronic and optical products and air and spacecraft and related machinery.

11 The manufacture of chemicals and chemical products, weapons and ammunition. The manufacture of electrical equipment. The manufacture of machinery and equipment, motor vehicles, trailers and semi-trailers, other transport equipment, and medical and dental instruments and supplies.

12 The reproduction of recorded media and the manufacture of coke and refined petroleum products, rubber and plastic products, non-metallic mineral products, basic metals and fabricated metal products (except machinery). The building of ships and boats. The repair and installation of machinery and equipment.

13 The manufacture of food products, beverages, tobacco products, textiles, apparel, leather and related products, wood and products of wood, paper and paper products. The printing and reproduction of recorded media. The manufacture of furniture. services $^{14}$ and less knowledge-intensive services $^{15}$ (Eurostat 2009).

The results reveal that in terms of STRENGTH of ownership links, firms from the high and medium-high-technology sectors attracting the most considerable amounts of foreign investment among cities in the CEECs, with this being mainly true of their capital cities (Fig. 7). More specifically, highest levels of FDI were mostly concerned attracted by firms in the CEECs that specialise in the manufacture of motor vehicles and of computers and peripheral equipment, or else accessories and electronic equipment for motor vehicles, electric motors, generators and transformers, or pharmaceutical preparations.

It is possible to identify an 'over-concentration' of these types of firms in Czechia, southern Poland (Silesia), western Slovakia (the Bratislava region) and northern Hungary (the Budapest area). The highest STRENGTH was

\footnotetext{
14 Knowledge-intensive services include: water transport, air transport, publishing activities, motion picture, video and television programme production, sound recording and music publishing activities, programming and broadcasting activities, telecommunications, computer programming, consultancy and related activities, information service activities, financial and insurance activities, legal and accounting activities, activities of head offices, management consultancy activities, architectural and engineering activities, technical testing and analysis, scientific research and development, advertising and market research, other professional, scientific and technical activities, veterinary activities, employment activities, security and investigation activities, public administration and defence, compulsory social security and education.

15 Less knowledge-intensive services incorporate: wholesale and retail trade; repair of motor vehicles and motorcycles, land transport and transport via pipelines, warehousing and support activities for transportation, postal and courier activities, accommodation and food service activities, real estate activities, rental and leasing activities, travel agency, tour operator reservation service and related activities, services to buildings and landscape activities, office administrative, office support and other business support activities, activities of membership organizations, repair of computers and personal and household goods, other personal service activities, activities of households as employers of domestic personnel, undifferentiated goods and services-producing activities of private households for own use and activities of extraterritorial organizations and bodies.
} 


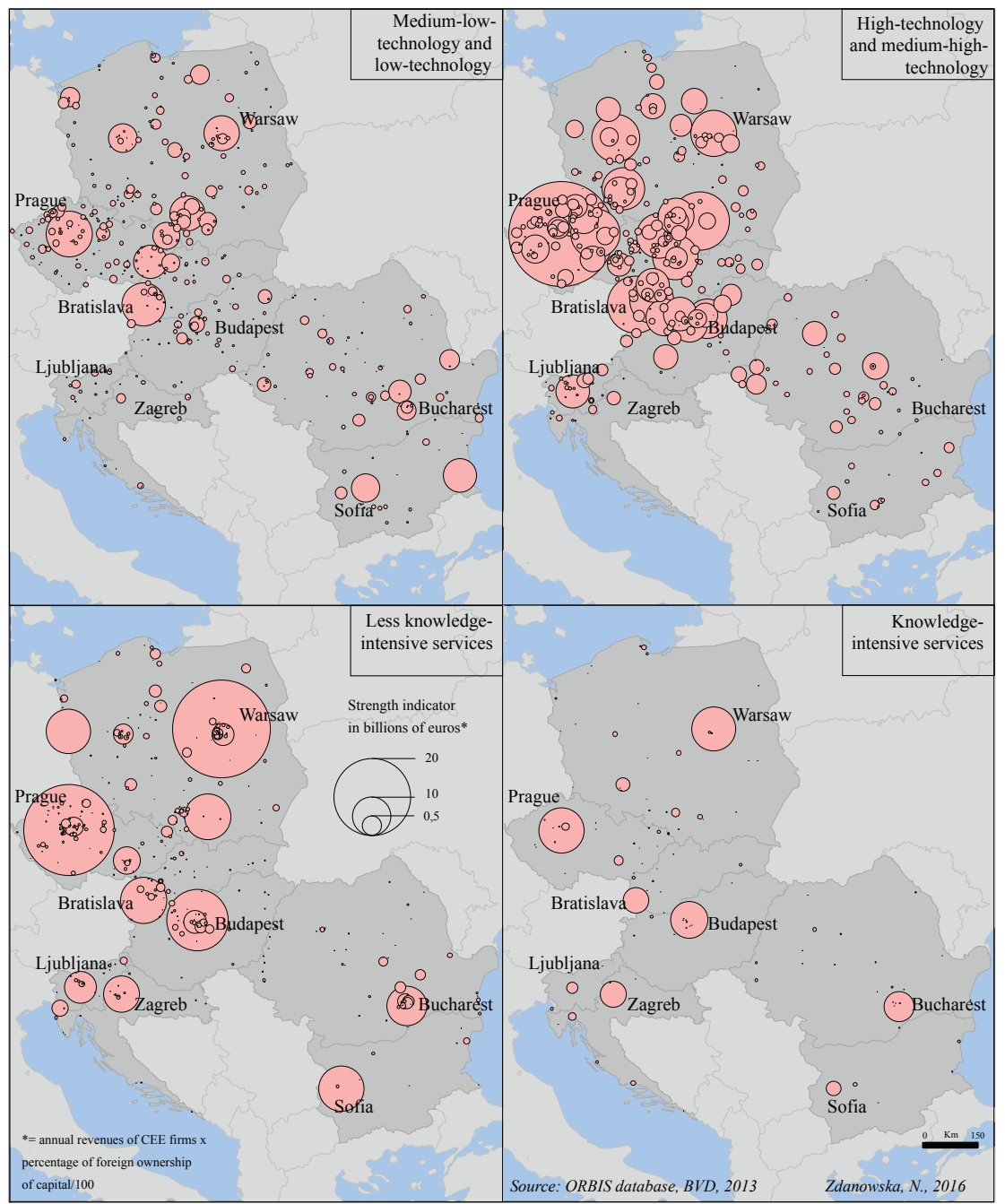

Figure 7. A comparison of the STRENGTH generated by CEE firms owned by foreign companies in the manufacturing and services sectors in billions of euros as of 2013

generated by firms in the automotive industry present in the region, i.e. Skoda Auto a.s. in Prague, Volkswagen Slovakia a.s. in Bratislava, Fiat Auto Poland S.A. in Kraków, Kia Motors Slovakia s.r.o. in Teplicka na Vahom (Slovakia), Hyundai Motor Manufacturing Czech s.r.o. in Ostrava or General Motors Manufacturing Poland sp. z o.o. in Katowice. This observation can thus be said to concern an 'automotive triangle' in Central Europe (see also Albert-Bohan 2015). An interesting fact is that these firms are not solely located in capital cities, as was observed previously, but are also present in medium-sized industrial cities around Ostrava or the Katowice conurbation, i.e. areas having a historical industrial background as parts of the 'old industrial regions' (Baranyai \& Lux 2014: 133).

Companies from the middle-low and lowtechnology sectors responsible for generating the most marked STRENGTH indicator in 2013, were specialised in the manufacture 
of refined petroleum products, basic metals or rubber products, or else in copper production. More precisely, this was true of: Slovnaft a.s. in Bratislava owned by Mol Magyar OlajEs Gazipari Rt. in Budapest, Unipetrol a.s. in Prague owned by Polski Koncern Naftowy Orlen S.A. in Warsaw and Arcelormittal Poland S.A. in Dąbrowa Górnicza owned by Arcelormittal France in Paris. The interesting fact is that FDI in the middle-low and low-technology sectors offers the only cases in which rather middle-sized or small cities are involved. Indeed, industrial activities of this kind emerge as only rarely located in large cities. The cities involved here specifically are Dąrowa Górnicza (investment of the Paris-based Arcelormittal France), Burgas (investment by Lukoil Europe Holdings B.V. headquartered in Amsterdam), Pirdop (investment by Cumerio Austria Gmbh in Vienna) and Otrokovice (investment by Continental Holding France from Sarreguemines).

The STRENGTH generated by the knowledge-intensive firms (E. On Hungaria Energetikai Zartkoruen Mukodo Reszvenytarsasag in Budapest, Ina-Industrija Nafte d.d. in Zagreb, Polska Telefonia Cyfrowa S.A. in Warsaw and Telefonica Czech Republic a.s. in Prague) is rather scarce when compared with firms in the 'less knowledge-intensive' sector (Carrefour Polska Sp. z o.o. in Warsaw, Tesco Polska Sp. z o.o. in Kraków, Makro Cash \& Carry CR s.r.o. in Prague, Auchan Magyarorszag in Budapest). In both categories of sector, headquarters attracting most of FDI tend to be located in capital cities.

This section has permitted identification of the main destinations of foreign direct investment in cities of the CEECs, as viewed from the point of view of different types of indicator and activity sector. In every case a clear predominance of the role of the CEECs' capital cities has been observed (Marinova \& Marinov 2005). Foreign owners tend to invest in firms where the locations of $\mathrm{HQs}$ are associated with localities higher up in the administrative hierarchy, whilst simultaneously having a large number of affiliates (Śleszyński 2007).

\section{Conclusion}

The analysis shows that main foreign investors of capital in Central and Eastern Europe in most cases come from other member states of the European Union, only then followed by non-European countries, other CEECs and finally (representing small quantities in numerical terms) from post-communist countries outside the European Union. More specifically, EU ownership comes mainly from The Netherlands, Germany and France, with the attraction being the proximity of the market comprised by the CEECs and targeted mainly at the manufacture of motor vehicles (Skoda Auto a.s), trade in gas (RWE Transgas a.s.) and pharmaceutical preparations (Lek Farmacevtska Druzba d.d). In addition, the study shows that, even if relations between CEE firms represent only $8.3 \%$ of all investment for some countries like Croatia or Slovakia, investments from the CEECs respectively account for up to $33.3 \%$ and $20.3 \%$ of total investments. Moreover CEE relations are very unbalanced, as Hungary, Czechia and Poland seem to be the dominant CEE investors in other CEE countries. Romania is the country most invested in, while at the same time investing least itself. The proximity effect is of great importance in the case of intra-CEE relationships, as was revealed by the privileged ownership links pertaining between firms in Poland and Czechia, Slovenia and Croatia, as well as Romania and Hungary. At city-to-city level Budapest and Bratislava are the most connected cities in terms of amount of foreign investment among the CEECs, with this reflecting the Hungarian gas and oil company MOL being the owner of Slovak firm Slovaft.

Furthermore, the results revealed that, as in the 1990s and 2000s, so also in 2013, cities involved in the process of FDI inflow in the CEECs are mainly capitals or medium-sized cities, which follow the urban patterns of each national urban system closely. In fact, it seems that metropolisation has rather contributed to a raising of the predominance of the capital cities in the CEECs' urban systems, rather than to any diminution of inequalities between cities 
even in relatively polycentric urban systems like that of Poland (Zdanowska 2015, 2016). Within the CEE capitals, foreign ownership was concentrated mainly in Prague where level of FDI in euros was concerned, as followed by Warsaw, Bucharest, Bratislava, Budapest, Kraków, Sofia and Zagreb. Nevertheless, if the level of investment is aggregated at national level, Poland is found to maintain first position. It can then be deduced that in Poland FDI has been more widely dispatched to other cities as well as just merely the capital city.

This locating of FDI varies with the different activity sectors firms in the CEECs, though again tending to concern headquarters in large cities, with this again showing how FDI distribution is related to that of urban areas. Capital cities are the most involved in investments in the high and medium-high-technology sectors, as well as in the knowledge-intensive and less knowledge-intensive services sectors. The headquarters of firms in medium-sized cities in Silesia are more taken up by FDI in the medium-low and low-technology sectors. The results also showed a striking predominance of participation in CEE firms on the part of the services sector (75\% of firms), in comparison with manufacturing industry (just 26\%) in 2013. In terms of STRENGTH of ownership links, firms from the high and medium-hightechnology sectors have a more important role to play, with an overconcentration in Czechia,

\section{References}

AlBert-Bohan C., 2015. Les stratégies des firmes multinationales automobiles dans les villes de l'élargissement européen : réseaux urbains et organisation en chaine globale de valeur. University of Lausanne [PhD thesis; typescript].

Baranyal N., Lux G., 2014. Upper Silesia: The revival of a traditional industrial region in Poland. Regional Statistics, vol. 4, no. 2, pp. 126-144.

BitzenIS A., 2004. Explanatory variables for low Western investment interest in Bulgaria. Eastern European Economic, vol. 42, no. 6, pp. 5-38. the South of Poland (Silesia), western Slovakia (the Bratislava region) and the north of Hungary (around Budapest).

The role of cities in the process of globalisation has been crucial, and so it is not surprising that those able to offer the best opportunities have attracted the headquarters of large international firms, and the FDI that goes with that. In Central and Eastern Europe, capital cities were the first to offer this kind of openness to the Western world, in the early 1990s (Bourdeau-Lepage 2004). The concentration of firms' headquarters in the CEECs' capital cities is mainly related to centralisation of the main state-owned companies inherited from the communist period, and to the proximity to political institutions and other services that is made possible (Śleszyński 2007). In spite of this tendency, the results of the work described here show that, Poland's contemporary economic management centres controlled by foreign owners are to a greater degree located in secondary cities here than is the case of other CEECs. This phenomenon mainly reflects the more polycentric urban system present in Poland as opposed to in other CEE countries (Zdanowska 2016).

Editors' note:

Unless otherwise stated, the sources of tables and figures are the authors', on the basis of their own research.
Bourdeau-Lepage L., 2004. Varsovie une nouvelle métropole. GaWC Research Bulletin, no. 142, http://www.lboro.ac.uk/gawc/rb/rb142.html [23 April 2015].

BUČEK J., 2012. Crisis in Slovakia 2009-2010: From saving the economy to saving public finance [in:] G. Gorzelak et al. (eds.), Adaptability and Change: The Regional Dimensions in Central and Eastern Europe, Warszawa: Wydawnictwo Naukowe Scholar, pp. 334-359.

Carstensen K., Toubal F., 2004. Foreign direct investment in Central and Eastern European countries: A dynamic panel analysis. Journal of Comparative Economics, vol. 32, pp. 3-22. 
CieślıK A., 2005. Geografia inwestycji zagranicznych. Przyczyny i skutki lokalizacji spółek z udziałem kapitału zagranicznego w Polsce. Warszawa: Wydawnictwa Uniwersytetu Warszawskiego.

CIEŚLIK A., 2013. Determinants of the location of foreign firms in Polish regions: Does firm size matter? Tijdschrift voor Economische en Sociale Geografie, vol. 104, no. 2, pp.175-193.

Csomós G., Derudder B., 2014. European cities as command and control centres, 2006-11. European Urban and Regional Studies, vol. 21, no. 3, pp. 345-352.

Domański B., 2001. Kapitał zagraniczny w przemyśle Polski. Prawidłowości rozmieszczenia, uwarunkowania i skutki. Kraków: Instytut Geografii i Gospodarki Przestrzennej UJ.

DomAŃSKI B., 2011. Foreign capital and the development of Polish regions. Czasopismo Geograficzne, vol. 82, no. 1-2, pp. 173-187.

Domański B., Guzik R., Gwosdz K., 2000. Konkurencyjność i ranga wielkich miast Polski w świetle inwestycji zagranicznych firm produkcyjnych. Biuletyn KPZK PAN, no. 192, pp. 99-12.

Dostál P., 2008. The post-communist capital city effects, Transactional activities and regional development in the Czech Republic in the 1990s: A modelling approach [in:] W. Strubelt, G. Gorzelak (eds.), City and Regions, Papers in honour of Jiři Musil, Opladen: Budrich UniPress, pp. 15-42.

EUROSTAT, 2009. Aggregation of Knowledge Intensive Activities based on NACE Rev.2. Eurostat, http://ec.europa.eu/eurostat/cache/metadata/ Annexes/htec_esms_an8.pdf [23 April 2016].

Evans A.W., 1973. The location of the headquarters of industrial companies. Urban Studies, vol. 10, no. 3, pp. 387-395.

FinANCE O., 2014. Hiérarchie urbaine et ancrage territorial des firmes transnationales étrangères dans le système de villes français: une approche par les lois d'échelle. Proceedings of the conference «Aux frontières de l'urbain. Petites villes du monde: émergence, croissance, rôle économique et social, intégration territoriale, gouvernance», Avignon, pp. 378-395.

FinanCE O., 2016. Les villes françaises investies par les firmes transnationales étrangères: des réseaux d'entreprises aux établissements localisés. University Paris 1 Panthéon-Sorbonne [PhD thesis; typescript].
GÁLZ., 2013. Role of financial sector FDI in regional imbalances in Central and Eastern Europe [in:] A. Gostyńska et al. (eds.) Eurozone enlargement: Challenges for the V4 countries, Warsaw: The Polish Institute of International Affairs, pp. 27-35.

GAUTIER B., 2012. Intégration et développement des villes méditerranéennes par les réseaux de firmes multinationales du secteur agroalimentaire. University of Lausanne [PhD thesis; typescript].

Goschin Z., Luminita-Constantin D., Raluca-DanCIU A., 2010. A regional perspective on the impact of the current economic crisis in Romania. Romanian Economic and Business Review, vol. 5 , no. 3, pp. 204-225.

GuzIK R., GwosDz K., 2000. The spatial concentration of control functions in Polish industry [in:] T. Marszał (ed.), Local economy and urban development in Poland, Łódź: Department of the Built Environment and Spatial Policy, University of Łódź, pp. 52-61.

Hamilton I., Dimitrovska-Andrews K., PichlerMilanović N., 2005. Transformation of cities in central and Eastern Europe: Towards globalization. Tokyo, New York, Paris: United Nations Press.

Hilber C.A.L., Voicu I., 2010. Agglomeration economies and the location of foreign direct investment: Empirical evidence from Romania. Regional Studies, vol. 44, no. 3, pp. 355-371.

HUNYA G., 1998. Integration of CEEC manufacturing into European corporate structures by direct investments. MOST: Economic Policy in Transitional Economies, vol. 8, no. 2, pp. 69-90.

JOVANČEVIĆ R., 2007. The impact of foreign investments flows on Croatian economy - A comparative analysis. Ekonomski Pregled, vol. 58, no. 12, pp. 826-850.

KAMP B., 2007. Location behavior and relationship stability in international business networks: Evidence from the automotive networks. Routledge Studies in Business Organizations and Networks. London-New York: Routledge.

Karaszewski W., 2004. Bezpośrednie inwestycje zagraniczne. Polska na tle świata. Toruń: Dom Organizatora.

KILAR W., 2009. Koncentracja przestrzenna światowych firm informatycznych. Prace Komisji Geografii Przemysłu Polskiego Towarzystwa Geograficznego, no. 12, pp. 97-108. 
KILAR W., 2014. Differentiation of Visegrad Group international corporations in comparison to world's largest corporations [in:] D. KiendlWendner, K. Wach (eds.), International competitiveness in Visegrad Countries: Macro and micro perspectives, Graz: Fachhochschule Joanneum, pp. 171-186.

KILAR W., 2015. Settlement concentration of economic potential represented by IT corportations. Geographia Polonica, vol. 88, no. 1, pp. 123-141.

KISS E., 2014. Foreign direct investment in Hungary: Industry and its spatial effects. Eastern European Economics, vol. 45, no. 1, pp. 6-28.

Komornicki T., Korcelli P., SiŁKA P., ŚlesZYŃSKI P., ŚWIATtEK D., 2013. Powiqzania funkcjonalne pomiędzy polskimi metropoliami. Warszawa: Instytut Geografii i Przestrzennego Zagospodarowania PAN, Sedno.

Komornicki T., Szejgiec B., 2015. Spatial differentiation of Polish export linkages. Geographia Polonica, vol. 88, no. 1, pp. 173-179.

Korcelli-Olejniczak E., 2004. Funkcje metropolitarne Berlina i Warszawy w latach 1990-2002. Współzależności pozycji w systemie miast Europy. Prace Geograficzne, 198, Warszawa: Instytut Geografii i Przestrzennego Zagospodarowania, Polska Akademia Nauk.

Korcelli-Olejniczak E., 2012. Region metropolitalny - pojęcie, struktura przestrzenna, dynamika. Prace Geograficzne, 235, Warszawa: Instytut Geografii i Przestrzennego Zagospodarowania, Polska Akademia Nauk.

LePESANT G., 2011. Géographie économique de l'Europe centrale. Les nouveaux territoires européens. Paris: Presses de Sciences Po.

Luc S., 2000. Zagraniczne inwestycje bezpośrednie a przekształcenia strukturalne w przemyśle polskim. Monografie i Opracowania, no. 475, Warszawa: Szkoła Główna Handlowa.

Lux G., 2010. Location differences of services and industry: A Central European dichotomy. Prace Komisji Geografii Przemysłu Polskiego Towarzystwa Geograficznego, no. 16, pp. 29-37.

Marinova S.T., Marinov M.A. (eds.), 2003. Foreign direct investment in Central and Eastern Europe. Aldershot: Ashgate.

NowOSIELSKA E., 2001. Wielkie firmy usługowe w układzie nowych województw [in:] T. Czyż(ed.), Zróżnicowanie społeczno-gospodarcze w nowym układzie terytorialnym Polski, Biuletyn KPZK PAN, no. 197 , pp. 103-129.

OECD, 2013. Foreign direct investment. Paris: OECD Factbook 2013: Economic, Environmental and Social Statistics, DOI: 10.1787/ factbook-2013-en.

PakUlsKa T., Poniatowska-Jaksch M., 2004. Bezpośrednie inwestycje zagraniczne w Europie Środkowo-Wschodniej. Koncentracja kapitału zagranicznego w Polsce. Monografie i Opracowania, no. 519, Warszawa: Szkoła Główna Handlowa.

PavlíneK P., 2004. Regional development implications of foreign direct investment in Central Europe. European Urban and Regional Studies, vol. 11, no. 1, pp. 47-70.

PavlíneK P., DomańSKI B., GuZIK R., 2009. Industrial upgrading through foreign direct investment in Central European automotive manufacturing. European Urban and Regional Studies, vol. 16, no. 1, pp. 43-63.

Pavlínek P., Smith A., 1998. Internationalization and embeddedness in East-Central European transition: The contrasting geographies of inward investment in the Czech and Slovak Republics. Regional Studies, vol. 32, no. 7, pp. 619-638.

POPESCU C., 2012. Foreign direct investment and regional development in Romania. Romanian Journal of Geography, vol. 56 no. 1 pp. 61-70.

POPESCU G.H., 2014. FDI and economic growth in Central and Eastern Europe. Sustainability, vol. 6, no. 11, pp. 8149-8163, http://www.mdpi. com/2071-1050/6/11/8149 [25 August 2015].

Pumain D, Rozenblat C., 2007. Firm linkages, innovation and the evolution of urban systems [in:] P. Taylor, B. Derudder, P. Saey, F. Witlox (eds.), Cities in globalization: Practices, policies and theories, London: Routledge, pp. 130-156.

PYKA R., 2011. La métropolisation en Pologne: le fonctionnement et l'avenir des espaces métropolitains polonais. Métropoles, no. 10, http:// metropoles.revues.org/4515 [15 May 2015].

Rozenblat C., Bellewald A., 2015. Pouvoirs et attractivités des villes françaises dans les réseaux des entreprises multinationales [in:] M-F. Mattei and D. Pumain (eds.), Données urbaines 7, Paris: Economica, pp. 261-274.

Rozenblat C., Dı Lello O., 2014. Les réseaux de firmes multinationales dans les villes d'Europe centre-orientale, Cybergeo: European Journal of Geography. Espace, Société, 
Territoire, document 678, http://cybergeo.revues.org/26325 [20 July 2014].

SAKALI C., 2013. Determinants of foreign direct investments (FDI) in Bulgaria: An econometric analysis using panel data. East-West Journal of Economics and Business, vol. 16, no. 1, pp. 73-97.

SASSEN S., 1991. The Global City. Princeton, NJ: Princeton University Press.

ŚLESZYŃSKI P., 2002. Struktura i rozmieszczenie ośrodków zarzqdzania w polskiej gospodarce w 2000 r. Przegląd Geograficzny, vol. 74, no. 2, pp. 199-228.

ŚLESZYŃSKI P., 2007. Gospodarcze funkcje kontrolne w przestrzeni Polski. Prace Geograficzne, 213, Warszawa: Instytut Geografii i Przestrzennego Zagospodarowania PAN.

ŚLESZYŃSKI P., 2008. Duże przedsiębiorstwa w strukturze przestrzennej największych polskich miast. Prace Geograficzne, 217, Warszawa: Instytut Geografii i Przestrzennego Zagospodarowania PAN.

ŚLESZYŃSKI P., 2014. Headquarters of large enterprises in the spatial structure of major Polish cities. Prace Komisji Przemysłu Polskiego Towarzystwa Geograficznego, no. 25, pp. 178-193.

ŚLESZYŃSKI P., 2015. Economic control functions in Poland in 2013. Geographia Polonica, vol. 88, no. 4, pp. 701-708.

SUCHÁČEK J., 2013. Urban potential for investment attraction in the Czech Republic. Finance and the Performance of Firms in Science, Education and Practice: Proceedings of the 6th international scientific conference, Zlín: Tomas Bata University, pp. 718-727.

SuCHÁČEK J., BARÁNEK P. 2012. Largest enterprises in the Czech Republic: A spatio-temporal perspective. Acta Universitatis Agriculturae et Silviculturae Mendelianae Brunensis, vol. 60, no. 7, pp. 329-336.

TAYlor Z., CieChański A., 2013. Bezpośrednie inwestycje zagraniczne w polskim transporcie.
Monografie, no. 15, Warszawa: Instytut Geografii i Przestrzennego Zagospodarowania PAN.

TAYLoR Z., CieChańsKI A., 2014. Funkcje kontrolne wielkich miast Polski w świetle bezpośrednich inwestycji zagranicznych $w$ transporcie. Przeglad Geograficzny, vol. 86, no. 2, pp. 141-170.

VANČURA M., 2006. Foreign direct investment in the countries of Central Europe with the emphasis on the Czech Republic [in:] T. Michalski (ed.), The geographical aspects of the transformation process in Central and East-Central Europe, GdyniaPelplin: Bernardinum, pp. 170-180.

Vandermotten C., Marissal P., Van Hamme G., 2010. La production des espaces économique. La formation du système-monde. Bruxelles: Université Libre de Bruxelles.

WęCtAWOWICZ G., 2010. Charakterystyka głównych trendów i zmian w rozwoju obszarów miejskich Polski. Warszawa: Ministerstwo Rozwoju Regionalnego, Departament Koordynacji Polityki Strukturalnej.

WendT J., 2001. Geografia władzy w Polsce. Gdańsk: Wydawnictwo Uniwersytetu Gdańskiego.

WYŻNIKIEWICZ B., 1997. Regionalne zróżnicowanie sity ekonomicznej (na podstawie "Listy 500" najwiękswych przedsiębiostw Gazety Bankowej) [in:] G. Gorzelak (ed.), Przemiany polskiej przestrzeni, Studia Regionalne i Lokalne, 19(52), Warszawa: Europejski Instytut Rozwoju Regionalnego i Lokalnego UW, pp. 205-228.

ZDANOWSKA N., 2015. Metropolisation and the evolution of systems of cities in the Czech Republic, Hungary and Poland since 1950. Deturope - The Central European Journal of Regional Development and Tourism, vol. 7, no. 2, pp. 4564, http://www.deturope.eu/img/upload/content_08241535.pdf [25 August 2012].

ZDANOWSKA N., 2016. Métropolisation et système de villes en Pologne depuis 1960. Revue Géographique de l'Est, vol. 56, no. 3-4, http:// rge.revues.org/5891 [25 August 2012].
(C) Natalia Zdanowska

(C) Geographia Polonica

(C) Institute of Geography and Spatial Organization

Polish Academy of Sciences - Warsaw • 2017
Article first received • September 2016 Article accepted - February 2017 